DOI:

УДК $621.7+539.64$

О.С. Баскевич, к.ф.-м.н., с.н.с., abaskevich@ukr.net

Державний вищий навчальний заклад "Український державний хіміко-технологічний університет", м. Дніпро, Україна

В.В. Соболєв, д.т.н., проф., velo1947@ukr.net

Національний технічний університет «Дніпровська політехніка», м. Дніпро, Україна

С.М. Ушеренко, д.т.н., проф., usherenko@gmail.com

Білоруський національний технічний університет, м. Мінськ, Білорусь

\title{
ФІЗИКО-МАТЕМАТИЧНА МОДЕЛЬ ВЗАЄМОДІЇ ВИСОКОШВИДКІСНОЇ ЧАСТИНКИ ЗІ СТАЛЕВОЮ ПЕРЕШКОДОЮ
}

У даній роботі на основі експериментальних даних проведено моделювання надглибокого проникання мікрочастинок мікронних розмірів в сталеву мімень та встановлені умов при яких відбуваються даний процес. Дослідження зіткнення потоку мікрочастинок з металевими перешкодами та процесів проникання їх на аномально великі глибини спрямовані на розв'язок фундаментальних завдань в області стійкості речовини та фазових перетворень. На основі отриманих експериментальних даних встановлено, що "надглибоке" проникання відбувається через глибокі структурні перетворення матеріалу перешкоди в вузьких граничних умовах обумовлених розмірними та швидкісними параметрами процесу зіткнення. Дані структурні зміни розглядаються як фазовий перехід, в результаті якого відбуваються об'ємні зміни в канальній зоні на протязі $10^{-7} \sim 10^{-6}$ с. В силу даних припущень, побудована модель та отриманні аналітичні вирази, заснована структурних змінах при "фазовому" переході. Запропонована модель дозволяє прогнозувати процеси керування структурними змінами і фізико-механічними властивостями оброблюваних матеріалів і в подальшому використовувати ї̈ для розробки технологічних прочесів легування та зміџнення.

Ключові слова: моделювання; надглибоке проникання; фазовий перехід; структурні зміни.

In this work, on the basis, of experimental data the design of super-deep penetration of microparticless of micronic sizes in a steel target and set terms at that take place this process. Researches of collision of stream of microparticless with metallic obstacles and processes of penetration of them on anomalously large depth directed to the decision of fundamental tasks in area of firmness of substance and phase transformations. It is set on the basis of the obtained experimental data, that "super-deep" penetration takes place through the deep structural converting of material of obstacle into the narrow maximum terms of conditioned by the size and speed parameters of process of collision. Given structural changes are examined as a phase transition as are sult of that there are by volume changes in a channel zone on a draught $10^{-7} \sim 10^{-6} \mathrm{~s}$ In force of these suppositions, built model and receipt analytical expression, founded structural change in "phase" transition. The offered model allows to forecast the processes of management structural changes and physics-mechanics properties of the processed materials and in future to use her for development of technological processes of alloying and strengthening.

Keywords: modelling; super-deep penetration; structural change; phase transition.

\section{Постановка проблеми}

Високоенергетична обробка матеріалів у комплексі з іншими видами фізичних впливів перебуває в числі пріоритетних науково-технічних досліджень, спрямованих на створення нових технологій і матеріалів різного функціонального призначення. Застосування одночасно двох і більше видів фізичних впливів на металеві поверхні пов'язане з одержанням нових фундаментальних знань, і з розв'язком таких актуальних завдань як створення нових енергозберігаючих технологій, одержання нових джерел енергії, і матеріалів 3 новими фізико-хімічними властивостями. 
Основна ідея комплексних обробок металевих матеріалів полягає в фізичних впливах на попередньо дестабілізовану мікроструктуру матеріалів. У якості ілюстрації нових результатів, отриманих при використанні комплексу обробок, можуть бути: синтез монокристалів метастабільного алмазу при ударному стиску, попередньо дестабілізованої системи графіт-метал [12]; переходи графіту та цирконію в аморфний стан при одночасній дії високого тиску та_опромінення потоками важких іонів [3]; аномально глибоке проникання мікрочастинок в метали 3 утворенням хімічних елементів, які до взаємодії були відсутні [4]. Із використанням стандартних експериментальних способів обробки металів подібні результати раніше в жодному експерименті не були отримані.

Високий ступінь фізико-хімічної активності твердих тіл та збільшення масштабів перетворень в їхній мікроструктурі відбуваються навіть при слабких енергетичних впливах, але тільки в тому випадку, якщо вихідний стан твердого тіла характеризується більшим запасом надлишкової внутрішньої енергії. Із цього погляду особливо показовими $є$ ефекти, виявлені в металах у результаті надглибокого проникання мікрочастинок.

Дослідження зіткнення потоку мікрочастинок з металевими перешкодами та процесів проникання їх на аномально великі глибини спрямовані на розв'язок фундаментальних завдань в області стійкості речовини та фазових перетворень. У процесі проникання мікрочастинок формується наномодифікований композиційний металевий матеріал, що представляє собою масивну металеву матрицю, насичену паралельно орієнтованими включеннями нової фази щільністю близько $(300 \ldots 1500) \times 10^{6} \mathrm{~m}^{-2}$ [1]. Такий композит з унікальною комбінацією фізичних, хімічних і механічних характеристик, використовувався для виготовлення та випробування дослідної партії різців у процесах руйнування кам'яного вугілля, калійної солі, різання металів [5].

Мікрочастинки проникають у масивні металеві перешкоди зі швидкістю співударяння $500 \ldots 3000$ м/с на глибини, що перевищують 0,1 м. Для порівняння, у випадку використання методу детонаційного напилювання (приблизно 3 такими ж швидкостями співударяння $300 \ldots 1000$ м/с) на поверхні перешкоди утворюються покриття, при цьому глибина проникання мікрочастинок у перешкоду не більше $6 \times 10^{-5} \mathrm{M}$. Експериментально встановлене, що формування умов переміщення мікрочастинок на аномально великі глибини обумовлене рядом процесів, викликаних фізичними особливостями формування згустку мікрочастинок у кумулятивному вибуховому прискорювачі $[1,4]$. В результаті зіткнення мікрочастинок 3 поверхнею масивної металевої перешкоди утворюються так звані кратери, глибина яких досягає 0,2 м. Сліди, що залишилися від мікрочастинки, що проникає, мають форму порожнини, у якої довжина перевищує поперечні розміри в $10^{5}$ разів.

Визначення механізму надглибокого проникання мікрочастинок в металеві мішені $\epsilon$ дуже актуальною задачею в сучасному матеріалознавстві.

\section{Аналіз останніх досліджень та публікацій}

Наявність фактів аномально надглибокого проникання (наведені глибини понад 10) свідчать про існування раніше невідомого механізму [6-8]. Аналіз літературних показав, що причиною може бути зміна масштабного фактору [7]. Запропонований поділ області взаємодії на три масштабні зони [9]. Макроскопічної вважається зона з розмірами більшими $10^{2}$ мм, мікроскопічної - $10^{-2}-10^{2}$ мм і субмікроскопічної - меншої $10^{-2}$ мм. В силу ряду причин найбільший розвиток одержали дослідження в макроскопічній зоні. Їхньою метою було визначення практичних конструкційних критеріїв. Вивчення субмікроскопічної області проводилося, в основному, для встановлення зв'язку між числом дислокацій і напругою. Аномальні результати спостерігалися в субмікрообласті та на границі з мікрообластю.

На певному етапі експериментальних досліджень було доведене існування ефекту "надглибокого" проникання і виникла нагальна потреба в розробці модельних припущень про "надглибоке" проникання, які дозволили б пояснити отримані експериментальні результати та визначити напрямок подальших досліджень.

Для пояснення експериментальних результатів можна запропонувати підхід, заснований на дослідженнях Фізико-технічного інституту ім. А.Ф. Іоффе РАН [10]. Процес проникання розглядається як результат розвитку тріщини. Отримані експериментальні дані дають тривалість процесу $10^{-7} \sim 10^{-6}$ с. При зіткненні двох твердих тіл виникає зростаюча в часі напруга. У 
деякий момент часу вона досягає рівня, що задовольняє відомому рівнянню кінетичної міцності. Виникають і ростуть субмікроскопічні осередки руйнування, що зливаються в тріщини. Міцність визначають амплітудним значенням напруги найменш інтенсивного імпульсу в результаті дії якого в зразку виникає шар. акустично непрозорий для розтягаючих напруг.

Розгляд процесу проникання як руху ударника у вершині тріщини цікаво, тому що вдається обійти питання додаткового підведення енергії до ударника при переміщенні в перешкоді. У цьому напрямку розбудовувалися модельні припущення Інституту механіки МГУ. Основною посилкою цих теоретичних досліджень $є$ допущення, що перешкода перебуває в пружному стані в плині всього періоду проникання $[11,12]$. Ця умова може бути виконана в тому випадку, якщо час дії імпульсу тиску згенерованого мікрочастинкою при русі через перетин перешкоди, менше часу запізнювання плинності матеріалу перешкоди. Час дії тиску визначається відношенням радіуса частинки до швидкості ії проникання Час запізнювання пластичної деформації - плинності залежить від динамічної межі плинності та постійних матеріалу перешкоди. Для сталі в відпаленому стані час запізнення оцінюється в $2-5$ мкс [13]. На думку авторів цих робіт період запізнення пластики в металі визначає обмеження розміру ударника (масштабний фактор). Однак, оцінка надглибокого проникання з позиції розвитку тріщини натрапляє на обмеження, пов'язані із присутністю інтенсивної пластики та теплових ефектів в зоні каналу. Необхідно було створення моделі тріщини у вигляді каналу. Спочатку це намагалися зробити у своїх роботах Г.Г. Чорний [11] і С.С. Григорян [12]. Розвитком цих робіт можна вважати якісну модель "надглибокого" проникання А.С. Рахімова [14].

\section{Формулювання мети дослідження}

Мета дослідження полягала у встановленні механізму надглибокого проникання мікрочастинок у металеві перешкоди та встановленні математичної залежності глибини проникання від основних фізичних параметрів мікрочастинки і металевої мішені.

\section{Виклад основного матеріалу}

Отримані експериментальні дані та встановлення того, що "надглибоке" проникання відбувається через глибокі структурні перетворення матеріалу перешкоди. А структурні зміни будемо розглядати як фазовий перехід. В результаті відбуваються об'ємні зміни в канальній зоні на протязі $10^{-7} \sim 10^{-6} \mathrm{c}$. В силу цього можливий розвиток модельних припущень, заснований на розгляді комплексу структурних змін як "фазового" переходу.

У певних умовах спостерігається стрибкоподібне падіння опору матеріалу. Це відповідає припущенням, висунутим у роботі $[1,3]$. Найбільш важливими 3 них є:

1. Метал поводиться так, ніби має місце тимчасова затримка деформаційного зміцнення в наслідок зменшення енергії зв'язку, яку спричиняє ударна хвиля.

2. Течія відбувається без зміцнення i, якщо вона вже почалася, то буде тривати доти, поки енергія в металі не опуститься нижче деякого рівня.

3. Час процесу визначається "критичною швидкістю" течії металу мішені.

4. Як тільки швидкість руху матеріалу перевищить критичну, деформація матеріалу вже не вимагатиме більших витрат енергії.

Фізико-хімічні особливості мікроструктурних перетворень і фазових переходів під впливом високих тисків вивчалися, наприклад, у роботах [15-21]. Автори визначають три можливості [19]:

1. Матеріал під дією ударної хвилі переходить у більш щільну фазу при цьому на кривій Гюгоніо з'являється "злам";

2. Фазовий перехід супроводжується збільшенням об'єму. У цьому випадку аномалій на кривих Гюгоніо не спостерігається;

3. Фазовий перехід не супроводжується будь-якою помітною зміною об'єму. Такий перехід не може бути виявлений безпосередньо в ударно-хвильових експериментах.

Відомо, що існують фазові переходи без додаткового збільшення та зі збільшенням внутрішньої енергії системи [20]. Переходи без збільшення протікають повніше і легше. Чим менш стабільна система, тобто більш метастабільний матеріал мішені, тем легше в ньому викликати за рахунок стрибка тиску фазовий перехід. Час фазового переходу оцінюється величиною порядку $10^{-7} \mathrm{c}[21]$. 
Під час фазового переходу стає характерним новий стан металевої речовини в процесі деформації [22]. Головною особливістю даного стану є деформування, що перешкоджає завершенню перетворенню. Проміжний стан, що виникає при розпаді старої і при утворенні нової фази, являє собою метастабільну фазу, у якій розбудовуються перетворення, загальмоване на стадії різкого зменшення енергії міжатомних зв'язків. Це обгрунтовується тим, що інтенсивний розпад кристалічної решітки метастабільних фаз у процесі деформації приводить атоми тіла в стан винятково високої рухливості, яка ніколи не виявляється у звичайних умовах. Відбувається своєрідна мікросекундна "аморфізація" металевої речовини. У цьому випадку визначається, що довжина вільної міграції атомів порівнюється з макроскопічними характеристиками тіла.

У структурі після бомбардування спостерігалися формоутворення, що мають "аморфізовану" будову. Це проявляється в тому, що навіть при великих збільшеннях $\left(\sim 10000^{\mathrm{x}}\right)$ не вдається спостерігати дроблення формоутворення на структурні елементи. Навколо цих утворень структура матричної сталі має поділ на елементи при суттєво менших збільшеннях. Іншим непрямим підтвердженням наявності "аморфізації" $є$ висока хімічна стійкість виникаючих дефектів. Третьою ознакою служить поява утворень, що мають вид застиглого розплаву.

За результатами досліджень, представлених у роботах [1,23-27], автори бачать причину надглибокого проникнення мікрочастинок в утворенні плазми на межі зіткнення мікрочастинки з перешкодою. Утворення плазми і відновлення ії під час проникання мікрочастинки знижує в'язкість на межі зіткнення до в'язкості, величина якої не перевищує в'язкість води. Рух мікрочастинки в об'ємі металу може бути описаний у гідродинамічному наближенні.

Припустимо, що в сталеву мішень під кутом $90^{\circ}$ ударилася мікрочастинка. Тиск, обумовлений швидкістю процесу зіткнення, виявилося достатнім для ініціювання фазового переходу в залізі ( $\mathrm{P}_{4} \sim 13$ Гпа). 3 поверхні взаємодії мікрочастинка-матриця поширюються три типи хвиль напруги. Це хвилі стиску — розрядження (поздовжні), хвилі зсуву (поперечні) і хвилі Релея, що поширюються уздовж поверхні. Граничні умови по швидкості можна визначити наступною нерівністю:

$$
V_{\kappa p}<V_{n p}<C_{t},
$$

де $C_{t}$ - швидкість поперечної ударної хвилі.

$$
v_{\kappa p}=P_{U} / \rho_{U} C_{t},
$$

де $P_{U}$ - тиск ініціювання динамічного фазового переходу.

При швидкості співударяння меншої, ніж $V_{\kappa p}(1+\lambda) / \lambda$, тиск виявляється нижчим необхідного для ініціювання фазового переходу. У випадку, коли швидкість співударяння більше, ніж $C_{t}(1+\lambda) / \lambda$ проникнення відбувається в області, де фазовий перехід ще не почався, і має місце деформаційне зміцнення:

$$
\frac{(\lambda+1) V_{\kappa p}}{\lambda}<V_{c}<\frac{(\lambda+1) C_{t}}{\lambda},
$$

де $\lambda-$ коефіцієнт при масовій швидкості частинок $(\approx 1,5-2,0)$.

Швидкість поперечної хвилі як найменша з об'ємних збурювань. Проникання ударника в мішень по аномальному механізму може відбуватися тільки в тому випадку, коли розмір ударника дорівнює або менше відповідного розміру області незавершеного фазового переходу.

Гранична умова за розмірами частинки має вигляд:

$$
K \leq d_{p d p} \leq \Delta h,
$$

де $d_{p d p}-$ максимальний розмір ударника, $\Delta h$ - розмір аморфізованої області, $K$ - розмір елементарного кристалічного гнізда даного матричного матеріалу. Розмір області залежить від величини імпульсу тиску та властивостей матричного матеріалу, тому що відповідає зоні, де напруги рівні або вище Р. Через протікання динамічного фазового переходу навколо кратера повинна виникати енергетична яма та рівень щільності енергії $d E / d V$ зростати. Це пов'язане зі 
зменшенням об'єму, на який витрачається основна частина енергії зіткнення. Причому вплив зниження об'єму виявляється більш істотним, ніж падіння величини енергії через зменшення розміру ударника:

$$
\Delta h \geq V_{n p} \cdot t_{\phi . n .}
$$

де $t_{\phi . n .}$ - час фазового переходу.

Розглянемо випадок взаємодії мікрочастинки дибориду титану $\left(\rho_{\psi}=4,38 \cdot 103 \mathrm{\kappa} / \mathrm{m}^{3}\right) \mathrm{i}$ мішені зі сталі $\left(\rho_{\mathcal{M}}=8,1 \cdot 103 \mathrm{\kappa} / \mathrm{m}^{3}\right)$ при швидкості співударяння $V_{c}=745 \mathrm{~m} / \mathrm{c}$, час фазового переходу приймемо $\sim 10^{-7} \mathrm{c}$ :

$$
V_{n p}=1 \cdot V_{c} / 1+\lambda=315 \mathrm{~m} / c, \Delta h=31,5 \text { мкм. }
$$

Аналіз експериментальних результатів показав, що $d_{p} d p$ для даного випадку дорівнює $\approx 80$ мкм. Помилка полягає в наближеній оцінці часу існування метастабільної проміжної фази (часу незавершеного фазового переходу). 3 обліком експериментальних даних проміжок часу можна уточнити:

$$
t_{\text {p.n. }}=d_{p} \cdot K_{p} / V_{n p}=2,53 \cdot 10^{-7} \mathrm{c} .
$$

Це значення відповідає даним роботи [28].

Збіг часу проникання та фазового переходу служить ще одним фактором, що обгрунтовує можливість створення несуперечливої теорії.

На підставі запропонованої моделі можна пояснити негативні значення розрахованої формально за експериментальними результатами "статичної" міцності матеріалу. При фазовому перетворенні, крім втрати стійкості кристалічної решітки, може відбуватися об'ємна зміна та витиснення "квазірідкого" матеріалу з каверни. Можливий викид зворотного струменю та позитивне прискорення ударника, що рухається. Експериментально цей ефект спостерігався в роботі [29]. Модель припускає вузькі рамки дії явища "надглибокого" проникання.

Існує механізм, що дозволяє надати частинці, що проникає додаткову енергію $\mathrm{E}>100 \cdot \mathrm{MU}^{2} / 2$. Причому ця енергія повинна надаватися частинці не одноразово (інакше швидкість частинки миттєво зростає та більша частина наданої енергії буде витрачена на теплове перетворення частинки і матеріалу перешкоди), а постійно, у на протязі всього часу руху частинки, частково або повністю компенсуючи її енерговитратні на подолання опору середовища.

Єдиним джерелом енергії, що підтримують процес "надглибокого" проникання, $є$ енергія потоку частинок. Більша частина цієї енергії існує в структурі матеріалу перешкоди у вигляді потенційної енергії поля тиску Р, що виникає слідом за фронтом хвилі стиску, що генерується у перешкоді потоком частинок.

Очевидно, що проникання частинки в перешкоду в умовах впливу на поверхню останньої порошкового потоку, супроводжується рядом особливостей, що дозволяють здійснити передачу частини енергії, що запасається потоком у структуру матеріалу перешкоди, деякої частки проникаючих частинок. Це можливо, коли тиск на передньому торці проникаючої частинки порівнюється з тиском на ії тильному торці. Канали, утворені в перешкоді, частинкою згортається під тиском, який ініціює потік частинок у перешкоді. Саме цей момент і відрізняє надглибоке проникання від процесу проникання одиночної частинки.

Розглянемо більш докладно процес сходження стінок області розрядження z (рис.1) перешкоди, що виникає в матеріалі, слідом за рухом частинки. Тиск $P_{z}$ в області $z$ набагато нижче тиску, створюваного потоком частинок у перешкоді Р. Знеміцнений квазірідкий матеріал перешкоди, що обтікає частинку, під дією різниці тисків $\mathrm{P}-\mathrm{P}_{2}$ розпочинає рухатися в радіальному напрямку $r$ і на деякій відстані від частинки канал сходиться під кутом:

$$
a=\arccos \left(U /\left(U^{2}+W^{2}\right)^{1 / 2}\right),
$$

де $W$ - складова швидкості стінок каналу, спрямована по осі руху частинки. У тому випадку, коли $a>a \kappa p$, де акp - критичний кут струменеутворення [30], із точки контакту О (рис. 1) виникає струмінь рідини $\mathrm{G}$, що доганяє частку (наздоганяючий струмінь, НC). Коли НС доганяє частинку і гальмується на ії тильній поверхні, частина енергії струменя передається ударникові 
і може бути витрачена їм на подолання сили опору перешкоди. Швидкість руху НС щодо точки контакту може бути обчислена за умови збереження інтеграла Бернуллі уздовж лінії струму. Ця величина буде зберігатися по лінії АСВВ, якщо час сходження каналу $\tau_{c x}<<\tau_{\partial s}$, де $\tau_{\partial s}$ - повний час руху частинки. У такому випадку, швидкість частинки II за час $\tau_{c x}$ змінюється незначно, iї рух можна вважати квазістаціонарним $\partial u / \partial t=0$. Зміна повної швидкості збіжного потоку (стінок каналу)

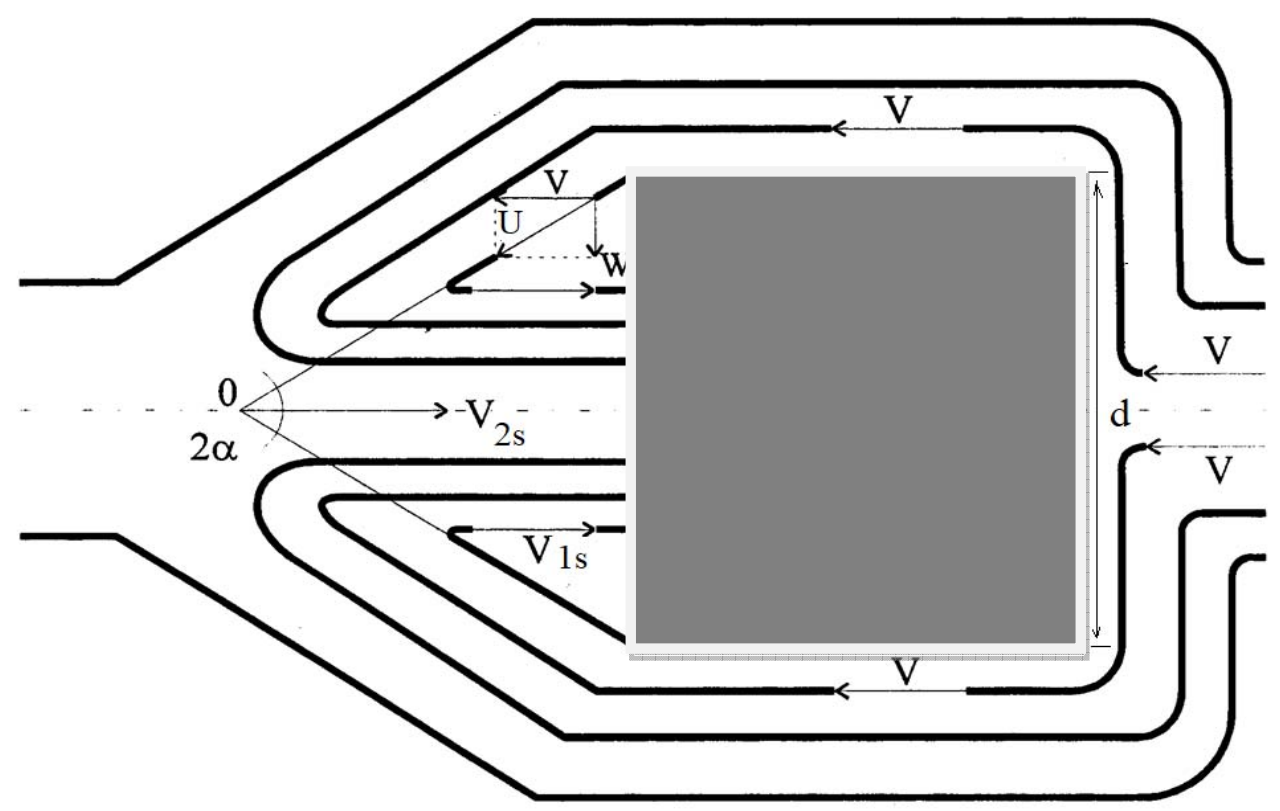

Puc. 1. Обтікання частинки розупорядоченим матеріалом перешкоди в умовах існування в ній поля тиску. Система координат, пов’язана зі спостерігачем

$$
\partial u / \partial t=\partial\left(W^{2}+U^{2}\right) / \partial t=\left[U /\left(W^{2}+U^{2}\right)\right](\partial U / \partial t)+\left[W /\left(U^{2}+W^{2}\right)\right](\partial U / \partial t) .
$$

Швидкість $W=W(p, \rho), \epsilon$ функцією $p$ і $\rho$. Оскільки $p<10$ ГПа, то щільність змінюється несуттєво. Рідина можна вважати нестисливою на протязі всього часу нагруження $-\partial \rho / \partial t=0$. Час $\tau_{c x}<<\tau_{o}\left(\tau_{o} \geq \tau_{\partial \varepsilon}\right)$, зміною тиску можна зневажити. Отже, $\partial p / \partial t=0$ i $\partial W / \partial t=0$. Звідси $\partial u / \partial t \approx \partial U / \partial t=0$.

Течію вздовж лінії струму АВСВ можна вважати стаціонарною. Інтеграл Бернуллі вздовж АВСВ зберігається:

$$
p / \rho+U^{2} / 2=\text { const. }
$$

Для будь-якої ділянки ВР (або BD):

$$
p_{z} / \rho+u^{2} / 2=p / \rho+U^{2} / 2
$$

де $p_{z}<<p$. Отже:

$$
u^{2}=2 \Delta p / \rho+U^{2}, \quad \Delta p=p-p_{z}
$$

i

$$
W=\left(u^{2}-U^{2}\right)^{1 / 2}=(2 \Delta p / \rho)^{1 / 2}, \quad U_{y}=u \cdot \operatorname{tg} \alpha .
$$

Швидкість руху НС щодо точки контакту О

$$
U_{1}=u \text {. }
$$

Швидкість руху точки в лабораторній системі координат 


$$
U_{2}=\frac{u}{\cos \alpha}=u\left(1+\frac{2 \Delta p}{\rho U^{2}}\right)=U\left(1+\frac{2 \Delta p}{\rho U^{2}}\right) .
$$

Повна швидкість переміщення струменя $V=U_{1}+U_{2}>2 u, u>U$. Отже, струмінь швидко (на протязі $\tau \approx d /(2 u)$ ) доганяє частинку і гальмується на його поверхні. Сила, що діє на ударник з боку поля тиску:

$$
F=\frac{\rho S_{1}\left(U_{1}+U_{2}-U\right)^{2}}{2}+\rho_{z}\left(S-S_{1}\right)-p S_{1},
$$

де $S_{1}$ - площа контакту струменя із частинкою.

Швидкість точки $\mathrm{O} U_{2}>u$, а $u>U$. Точка контакту доганяє ударник. 3 виходом їі на тильну поверхню частинки порожнина 2 заповнюється розупорядкованим матеріалом перешкоди, тиск в ній $P_{2} \rightarrow P$ и $\Delta p \rightarrow 0$. Тоді з (1) випливає, що $U_{2}=U, S_{I}=S$ і $U_{l}=V$. Отже:

$$
F=p \frac{V^{2} s}{2} \text {. }
$$

Підставимо (2) у формулу:

$$
M\left(\frac{d u}{d t}\right) \approx-\frac{\rho U^{2} S}{2}+F,
$$

де $M, S$ і $U$ - маса, міделевий перетин і миттєва швидкість частинки, $F$ - сила, обумовлена полем тиску в перешкоді. Одержуємо

$$
M\left(\frac{d u}{d t}\right)=0, M \neq 0 .
$$

Частинка рухається рівномірно зі швидкістю $U_{*}$, досягнутої до моменту повного закриття каналу (режим, що встановився). Витрати енергії на подолання сили опору повністю компенсуються. Реалізується парадокс Даламбера - рух без опору.

Процес проникання до моменту виходу частинки на режимі стаціонарного (рівномірного) руху складається із двох частин:

1. Проникання частинки на глибину $\cong l$. Рівносповільнений процес. Час руху $\tau_{\partial в}$. тривалість:

2. Рух частинки до моменту повного згортання каналу. Процес уповільнений, а його

$$
\tau_{c x} \cong \frac{0.5 d}{W}=0,5 d \cdot\left\lceil\frac{\rho}{2 \Delta p}\right]^{\frac{1}{2}} .
$$

Значення визначається шляхом інтегрування (3), коли тиск на лівому торці частинки відсутній $(P=-p S)$ при початковій умові:

$$
U\left(t-t_{o}\right)=U_{o}, x\left(t-t_{o}\right)
$$

і граничній умові, рівній $U_{*}=\left(t=\tau_{c x}+\tau_{\partial в}\right)$ :

$$
U_{*}=\left(\frac{2 \rho}{2 p}\right)^{1 / 2} \operatorname{tg}\left[\operatorname{arctg}\left(\frac{U_{0}^{2} \rho}{2 p}\right)-\left(\frac{\rho S}{2 M}\right) \cdot\left(\frac{2 p}{\rho}\right)^{1 / 2} \cdot\left(\tau_{c x}+\tau_{\partial \theta}\right)\right] .
$$

Величина $\tau_{\partial \varepsilon}$ також визначається за допомогою інтегрування (4) за умови $\tau=\tau_{\partial \varepsilon}$ коли $x=l$ :

$$
\tau_{\partial B}=\left(\frac{2 M}{\rho S}\right)\left(\frac{\rho}{2 p}\right)^{1 / 2}\left[\operatorname{arctg}\left(\frac{\rho U_{0}^{2}}{2 p}\right)-\operatorname{acrtg}\left[\left(1+\frac{\rho U_{0}^{2}}{2 p}\right) \gamma-1\right]^{1 / 2}\right] .
$$

Отже,

$$
U_{*}=\left(\frac{2 p}{\rho}\right)^{1 / 2} \operatorname{tg}\left[\operatorname{arctg}\left[\left(1+\frac{\rho U_{0}^{2}}{2 p}\right) \gamma-1\right]^{1 / 2}-\frac{p d}{4 \rho_{*} l}\right], \quad \gamma=\exp \left(-\frac{\rho}{\rho_{*}}\right) \text {. }
$$


Час взаємодії потоку з перешкодою $\tau_{o}=10^{-4}-10^{-5}$ с. Весь цей час частинка переміщується рівномірно зі швидкістю $U_{O}$. Глибина проникання частинки

$$
h_{*} \approx U *\left(\tau_{o}-t_{o}\right) .
$$

Величина $t_{o}$ визначає початок взаємодії даної частинки 3 перешкодою та відлічується від моменту початку взаємодії з нею потоку частинок $\left(O<t_{o}<\tau_{o}\right)$. Для $W$ при $t_{o}=0-U_{o}=$ $850,9 \mathrm{M} / \mathrm{c}, \tau_{o}=7,0-10^{-5} 3, h_{*}=6,0-10^{-2}$ м або $h_{* / d} \approx 6000$. У більш загальному випадку, коли параметри потоку змінюються із часом $p=p(t)$, то глибина проникання буде

$$
h_{*}\left(t_{o}\right)=\int_{t_{o}}^{\tau_{o}} U_{o}(t) d t .
$$

Інтеграл (6) у квадратурах не обчислюється. Глибину проникання в цьому випадку встановлювали шляхом чисельного інтегрування. На рис. 2 зображена залежність глибини проникання окремої частинки від іiі місця в потоці порошку $W$ (визначається параметром $t_{o}$ ). Матеріал мішені - залізо. Як і у випадку постійного поля тиску (5) ця залежність досить близька до лінійної, що свідчить про коректність методу визначення параметрів проникання при використанні усереднених за часом параметрів потоку частинок.

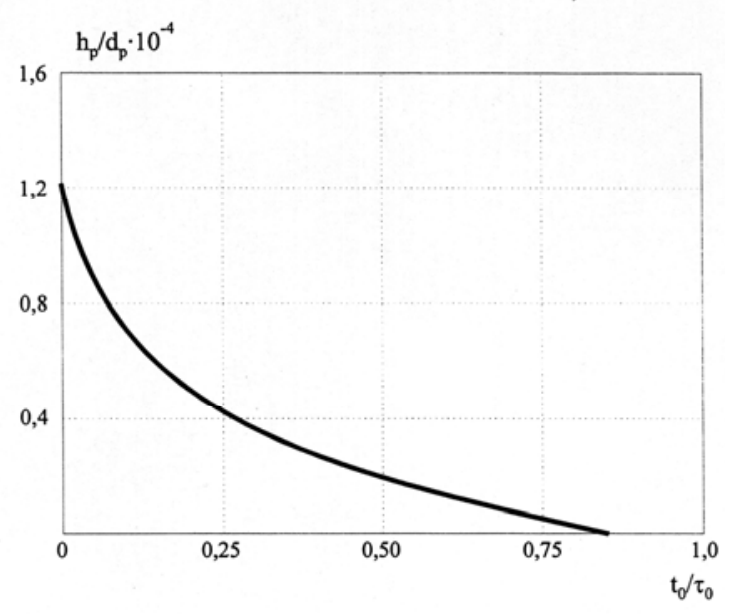

$a$

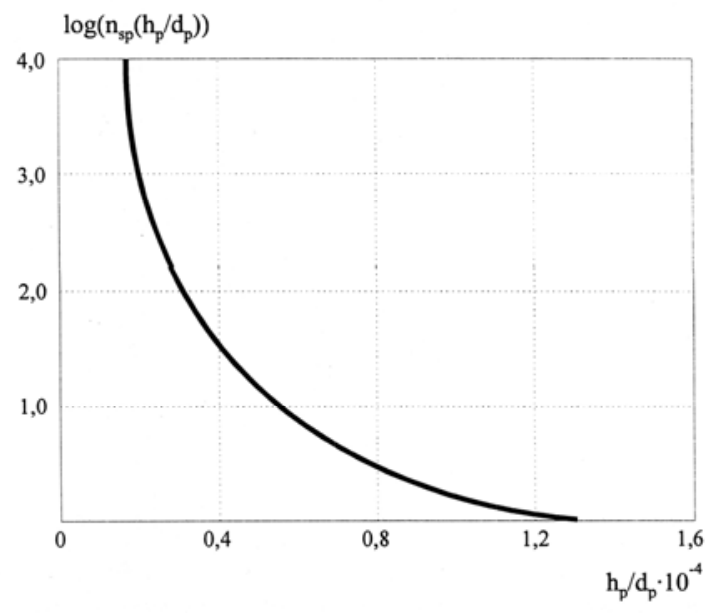

$\sigma$

Puc. 2. Залежності $h * / d$ від $t_{o} / \tau_{o}(a)$ і $n_{s}$ від $h * / d(б)$

Користуючись (5) або (6), можна встановити розподіл частинок порошку в перешкоді. Оскільки відома щільність потоку частинок $\rho_{n}(t)$, їх геометричні розміри $l=d$, а також площа перетину потоку, число частинок при кожному фіксованому перетині потоку:

$$
n_{o}\left(t_{o}\right)-\left(\frac{\rho_{n}\left(t_{o}\right)}{\rho_{*}}\right)\left(\frac{D\left(t_{o}\right)}{d}\right)^{2},
$$

де $D\left(t_{o}\right)$ - діаметр перетину. Чисельне значення цієї величини визначається цифрою $10^{7}-10^{6}$. Для визначення числа проникнених частинок необхідно оцінити частину частинок потоку $\xi$, що проникають у перешкоду, тоді щільність частинок на глибині $h_{*}\left(t_{o}\right)$ визначається величиною

$$
n_{p}\left(t_{o}\right)=\xi n_{o}\left(t_{o}\right)
$$

Значення $\xi$ визначається декількома факторами: 
1. Переважне положення займають частинки, що рухаються в напрямку, близькому до напрямку нормалі, відновлюваної до поверхні перешкоди $\left(\Delta< \pm 10^{\circ}\right)$. Для інших напрямків стає істотним вплив відбиття від поверхні перешкоди.

2. Величина $\xi$, визначається ефектами загородження та цілою групою специфічних процесів, що мають місце при переміщенні потоку частинок. Зіткнення, що відбуваються в потоці частинок можуть суттєво вплинути на розподіл кінетичної енергії потоку, а також на розподіл частинок по кутах. Число зіткнень кожної окремої частинки $z$ :

$$
z=\frac{H_{a}}{t_{z}}
$$

де

$$
l_{z}=\left(\pi \sqrt{2} d^{2} n\right)^{-1},
$$

$H_{a}$ - довжина $\mathrm{PO}, l_{z}$ - по аналогії з газом - довжина вільного пробігу частинки, $n=\rho_{n} / m$ — число частинок в одиниці об'єму, $m=\pi d^{2} l \rho * / 4-$ маса частинки. У такому випадку

$$
z=\left(\frac{\sqrt{2}}{4}\right)\left(\frac{\rho_{n} H_{a}}{\rho_{*} l}\right) \approx 3 \cdot 10^{2} .
$$

Отже, кожна частинка може змінити свій напрямок руху за час $\tau_{o}$ близько 300 раз. Імовірність того, що напрямок руху частинки виявиться близьким до напрямку нормалі до поверхні, перебуває в оберненопропорційній залежності від числа зіткнень. Тому $\xi \approx z^{-1} \approx 0,003$.

Площа, оброблювана потоком частинок $s_{n}\left(l_{0}\right) \approx(5 \pm 7) * 10^{-4} \mathrm{M}^{2}$. Щільність частинок на

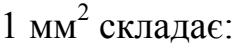

$$
n_{S}\left(t_{o}\right) \approx \frac{10^{-6} n_{o}\left(t_{o}\right)}{s_{n}\left(t_{o}\right)} \approx 10^{4} \mathcal{M M}^{-2} .
$$

Число проникаючих частинок на 1 мм $^{2}$ у момент часу $t_{0}$ :

$$
n_{p s}\left(t_{o}\right) \approx \frac{10^{-6} \xi \cdot n_{o}\left(t_{o}\right)}{s_{n}\left(t_{o}\right)} \approx n_{S}\left(t_{o}\right) \xi .
$$

Значення $n_{s}\left(t_{o}\right)$ і $\xi$ відомі. Залежність $n_{p s}\left(t_{o}\right)$ від глибини проникання $h_{*}\left(t_{o}\right)$ наведена на рис.2. Гранична глибина проникання $h m$ при цьому складе для $W$ близько $12,0110^{-2}$ або $h \mathrm{~m} / \mathrm{d}=12000$ Число частинок, що перебувають на цій глибині незначне $\approx 1,0 \cdot 10^{9}-2 \cdot 10^{9}$ (або 0,54 $-1,08 \mathrm{mм}^{-2}$ ). Зі зменшенням $h$ число частинок зростає, досягаючи $10^{4}-5 \cdot 10^{4}$ на глибині 6 мм. Поблизу поверхні $\left(h<1\right.$ мм) ця величина складає $10^{5}-10^{6}\left(200-2000 \mathrm{mм}^{-2}\right)$.

Отже, повне число проникаючих частинок визначається величиною $\approx 10^{6}$, що становить $\leq 1 \%$ від їхньої загальної кількості $\left(10^{11}-10^{10}\right)$.

Інші частинки загальмувалися на поверхні перешкоди ( $\approx 99,9 \%)$. Енергія, передана ними, i забезпечувала надглибоке проникання. Число каналів на глибинах $n_{s}\left(t_{o}\right)<h m$ буде значно більшим. Так, при $h_{*} \approx 6$ мм ця цифра принаймні на порядок перевершує $n_{p s}$ і складе $10^{2} \mathrm{~mm}^{-2}$,що добре узгодиться з результатами експерименту.

Слід зазначити, що "надглибоке" проникання можливе в тому випадку, коли частинка виявляється здатною подолати опір перешкоди на початковій ділянці траєкторії, маючи до початку стаціонарного руху ненульову швидкість $\left(\mathrm{U}_{*}>0\right)$. Враховуючи (6), цю умову можна записати у вигляді:

$$
\left(\frac{\rho U_{0}^{2}}{2 p}\right) \geq\left[1+\operatorname{tg}\left(\frac{2 \rho d}{4 l \rho_{*}}\right)\right] \gamma^{-1}-1
$$

або, оскільки $U_{0 \ll} U_{n}$, а $p=\kappa \rho_{n} U_{n} c$ :

$$
U_{n} \geq 2\left(\frac{\rho_{n}}{\rho}\right) k c\left[\left(1+\operatorname{tg}^{2}\left(\frac{2 \rho d}{4 \rho * l}\right)\right) \gamma^{-1}-1\right]=U_{\kappa p} .
$$


Описаний механізм може бути реалізований в умовах локального розупорядкування матеріалу перешкоди поблизу області взаємодії в на протязі часу $\tau=\tau_{\mathrm{g}}+\tau_{\mathrm{cx}}$. Отже, умову $\tau_{\mathrm{g}} \leq \tau_{\mathrm{p}}$ необхідно розглядати трохи ширше:

$$
\tau_{g}+\tau_{c x} \leq \tau_{p}
$$

Підставляючи сюди значення $\tau_{g}, \tau_{c x} \mathrm{i} \tau_{p}$, одержимо нерівність, що обмежує розміри проникаючих частинок залежно від властивостей перешкоди та параметрів потоку:

$$
d \leq d_{\kappa p}=\left(\frac{\lambda^{-2}}{a^{2}}\right) U_{o}\left(\frac{2 p}{\rho U_{0}^{2}}\right)^{1 / 2}\left[1+\left(\frac{2 p}{\rho U_{*}^{2}}\right)\right]^{-1} .
$$

Якщо $p \rightarrow 0$ ( $U_{n} \rightarrow 0$, тому що $\rho_{n} \neq 0, k$ і $c$ - постійні), то $d_{k p}=0$.

Однак, значення $p \rightarrow 0$ можливо тільки при відсутності потоку частинок. Отже, "надглибоке" проникання одиночної частинки у відсутності зовнішнього поля тиску неможливо. У тому випадку, коли $p \rightarrow \infty$, значення $d_{\kappa p}$ невизначене.

Умова (9) є математичним записом необхідної умови існування "надглибокого" проникання. Згортання каналу, утвореного частинкою в перешкоді, лише тоді приводить до утворення НС, коли кут сходження сходження $\alpha>\alpha_{k p}$, або $\cos \alpha<\cos \alpha_{k p}$. Оскільки $\cos \alpha=$ $U\left(U^{2}+W^{2}\right)^{1 / 2}, W=(2 p / \rho)^{1 / 2}$ одержуємо нерівність:

$$
p \leq p_{\kappa p}=\left(\frac{\rho U^{2}}{2}\right) \operatorname{tg}^{2} \alpha_{\kappa p},
$$

що є математичним формулюванням достатньої умови існування "надглибокого" проникання.

Існування в перешкоді поля тисків накладає обмеження на припустимі значення щільності потоку, що навантажує перешкоду. Ця умова:

$$
\rho_{n} \geq \rho_{* *} \text {, де } \rho_{* *} \approx 0,1 \rho_{*} \text {. }
$$

Чисельне значення критичних параметрів надглибокого проникання представлені в табл. 1.

Таблиия 1. Значення критичних параметрів надглибокого проникання при обробці сталевої перешкоди потоком порошку вольфраму

\begin{tabular}{|c|c|c|c|}
\hline$\rho_{* *}, \mathrm{\kappa} \Gamma \mathrm{M}^{2}$ & $p, \Gamma \Pi \mathrm{a}$ & $d, 10^{-6}$ & $U, \mathrm{M} / \mathrm{c}$ \\
\hline 1,95 & 0,711 & 129,5 & 461,8 \\
\hline
\end{tabular}

Формули (7-11) далеко не вичерпують усієї сукупності обмежувальних умов, що накладаються на проникання. Існує, наприклад, обмеження, пов'язане з формою частинок. Математично воно виражене у вимозі незаперечності виразу, що стоїть під знаком тангенса у формулі для $U_{*}$, звідки

$$
\frac{d}{l} \leq 4\left(\frac{\rho *}{\rho}\right) \operatorname{arctg}\left[\left(1+\left(\frac{\rho U_{0}^{2}}{2 p}\right)\right) \gamma-1\right]^{1 / 2} .
$$

Враховуючи, що в даному випадку навіть при $p \rightarrow \infty$ aгctg. $<\pi / 2$, одержимо:

$$
\frac{d}{l} \leq \frac{2 \pi \rho_{*}}{\rho} .
$$

Якщо швидкість потоку дуже велика ( $\approx 10$ км/с), тиск, реалізоване на поверхні перешкоди складе $100-150$ Гпа. Потік частинок діє на неї як кумулятивний струмінь. Якщо матеріал крихкий, то він при цьому може втратити свою цілісність. Дуже крихкі матеріали (скло, оргскло, сильно охолоджені метали і т.д.) руйнуються і при звичайних режимах навантаження.

\section{Висновки та перспективи подальших досліджень}

Надглибоке проникання мікроударників у перешкоду може відбуватися при виконанні двох основних умов: 
1. Необхідна умова. У результаті взаємодії, що супроводжується енерговиділенням на поверхні розділу ударник-перешкода, що відбувається на фоні постійного впливу на матеріал перешкоди імпульсів стиску, сформованих на ії поверхні потоком частинок, матеріал перешкоди в безпосередньо прилягаючої до частинки зони втрачає свою стійкість - розупорядковується.

2. Достатня умова. Тиск, що генерується потоком у матеріалі перешкоди, повинен бути таким, щоб у сліді, що згортається, за часткою каверни виникла НС, яка, гальмуючись на поверхні частинки, здійснює підштовхування (10). У даному випадку, енергія, що запасена потоком у матеріалі перешкоди у вигляді поля тиску, може поступово передаватися частинці, компенсуючи в такий спосіб іiі енерговитрати на подолання сил опору.

3. При прониканні мікрочастинок у сталеву перешкоду одночасно відбувається і гальмування ударників по глибині та їх дроблення.

4. Використання суміші порошкових матеріалів у порівнянні з одинарною порошковою сполукою забезпечує стабілізацію взаємодії та зменшення амплітуди коливань параметрів структури за глибиною.

5. На підставі експериментальних результатів взаємодії мікрочастинок з перешкодою виконана оцінка процесу проникання та установленню, що енергія зіткнення в основному витрачається на подолання динамічної міцності матеріалу перешкоди, а опір прониканню становить 2- 46 \% від динамічної границі текучості сталі.

6. Величина динамічної границі текучості для дослідженого випадку становить, залежно від розміру вихідного мікроударника, $10^{-1}-10^{-4}$ від спостережуваного при "статичних" навантаженнях.

7. У процесі надглибокого проникання мікрочастинок відбувається додаткове підведення енергії до ударника (54-98 \%) за рахунок структурних змін металу перешкоди та величини "статичної" міцності.

8. Запропонована модель "надглибокого" проникання діє у вузьких граничних умовах, обумовлених розмірними та швидкісними параметрами процесу зіткнення.

9. Модель, що використовуються в даній роботі, дозволяє прогнозувати процеси керування структурними змінами і відповідно фізико-механічними властивостями оброблюваних матеріалів і $€$ прийнятною для розробки технологічних процесів легування та зміцнення.

\section{Список використаної літератури}

1. Sobolev V.V. Mechanism of thick metal walls penetration by high-speed microparticles / V.V.Sobolev, O.S.Baskevych, L.M.Shyman, S.M.Usherenko // Науковий вісник НГУ. - 2016. № 6. - C. 75-83.

2. Sobolev V.V. Shock wave use for diamond synthesis / V.V. Sobolev, Y.N. Taran, S.I Gubenko. // Journal de Physique IV. Colloque. -1997. - P.73-75.

3. Glasmacher U.A. Phase Transitions in Solids Stimulated by Simultaneous Exposure to High Pressure and Relativistic Heavy Ions / U.A. Glasmacher, M. Lang, H. Keppler et al. // Physical Review Letters. - 2006. - 96, 195701.

4. Sobolev V.V. Shock-wave initiation of nuclear transmutation of chemical elements / V.V. Sobolev, S.M. Usherenko // Journal de Physique. IV. - 2006. - №134.- P. 977-982.

5. Ушеренко С.М. (1998). Сверхглубокое проникание микрочастиц в преграды и создание композиционных материалов / Ушеренко С.М. - Минск: НИИ импульсных процессов с опытным производством, 1998. -210 с.

6. Базилевский А.Т. Обзор достижений механики кратерообразования / А.Т. Базилевский, Б.А. Иванов // [Под ред. В.А. Николаевского]. Механика образования воронок при ударе и взрыве. - М.: Мир, 1977. - С. 178-227.

7. Гэннон Р.Е. Влияние бомбардировки микрочастицами на оптические свойства металлов / Р.Е. Гэннон, Т.С. Лашло, К.Е. Лей, С.Р. Уолник. // Ракетная техника и космонавтика. - 1965. т. 3, № 1. - C. 148-157. 
8. Котов Н.В. Легирование алюминия при скоростном соударении / Н.В. Котов, В.Я. Мухин, В.К. Шашкова и др. // Металловедение и прочность материалов. - Волгоград: Труды Волгоградского политехнического института, 1971, т. III. - С. 244-252.

9. Понд Р. Металлургические исследования и распределение энергии / Р. Понд, К. Гласе // [Под ред. В.А. Николаевского]. Высокоскоростные ударные явления. - М.: Мир, 1973. C. $428-467$.

10. Козлов Е.В. Длинномерные области напряжений и их роль в деформации структурнонеоднородных материалов / Е.В. Козлов, Д.В. Личагин, Н.А. Попова и др. // Сб. Физика прочности и пластичности гетерогенных материалов. - Ленинград: Изд-во Физикотехнического института, 1988. - С. 3-13.

11. Черный Г.Г. Механизм аномального сопротивления при движении тел в твердых средах Г.Г. / Черный // ДАН СССР. Теория упругости. -1987. - т. 292, № 6. - С. 1324-1328.

12. Григорян С.С. О природе "сверхглубокого" проникания твердых микрочастиц в твердые материалы / С.С. Григорян // ДАН СССР. Механика. - 1987. - т. 292, № 6. - С. 1319-1322.

13. Румянцев Б.В. Исследование динамических характеристик потока легирующих частиц кумулятивного заряда ВВ. Разработка взрывных устройств для создания потоков различной формы и геометрии / Б.В. Румянцев, О.В. Базанов, А.А. Мисаночников // Препринт СКТБ "Технолог", Ленинград, 1991. - С. 69.

14. Рахимов А.Э. Качественная модель сверхглубокого проникания / А.Э. Рахимов // Вести Московского университета. Математика. Механика, 1994. - сер. 1, № 5. - С. $72-74$.

15. Свойства конденсированных веществ при високих давлених и температурах / [Под ред.д.ф.-м.н. Р.Ф. Трунина]. - Арзамас: ВНИИЭФ, 1992. - 398 с.

16. Канель Г.И. Ударно-волновые явления в конденсированных средах / Канель Г.И., Разоренов С.В., Уткин А.В., Фортов В.Е. - М.: «Янус К», 1996. - 408 с.

17. Соболев В.В. Физика импульсной обработки материалов / В.В. Соболев, А.В.Ананьин, Т.Н.Балан, Н.И.Боримчук и др. / [Под ред. проф. В.В.Соболева]. - Днепропетровск: АРТ ПРЕСС, 2003. - $336 \mathrm{c}$.

18. Даниленко В.В. Взрыв: физика, техника, технология / В.В. Даниленко. -Москва: Энергоатомиздат, 2010. - $784 \mathrm{c}$.

19. Дерибас А.А. Физика упрочнения и сварки взрывом / А.А. Дерибас // Новосибирск: Наука, 1980. - С. 41-111.

20. Андилевко С.К. Исследование эффектов взаимодействия микрочастиц с металлической мишенью в условиях высоких давлений / С.К. Андилевко, В.Г. Городцов, К.И. Козорезов, С.М, Ушеренко // Сб. Физика и техника высоких давлений. - Киев: Наукова думка, 1984. № 17. - С. 82-85.

21. Креймер Г.С. Прочность твердых сплавов / Г.С. Креймер. - М: Недра, 1971. - 247 с.

22. Лаврентьев М.А., Шабат Б.В. Проблемы гидродинамики и ихматематические модели / М.А. Лаврентьев, Б.В. Шабат. - М.: Наука, 1977. - 408c.

23. Соболев В.В. Образование плазмы - как вероятная причина локальных разрушений в структуре материалов при ударно-волновой обработке / В.В. Соболев, С.М. Ушеренко // Украинский союз инженеров-взрывников. Информационный бюллетень. 2004. - №1(8). - С. 19-26.

24. Соболев В.В. Образование плазмы в ударно-волновых процессах / В.В.Соболев, С.М. Ушеренко // Физика и техника высоких давлений. - 2005. - Т.15, №2. - С.86-95.

25. Sobolev V.V. Formation of Plasma Focus at Superdeep Penetration of Microparticles in Solid/ V.V. Sobolev, S.M. Usherenko // Nonequilibrium Phnomena: Plasma, Combustion Atmosphere / [Edited by G.D.Roy, S.M. Frolov, A.M.Starik]. -Moscow: Torus Press Ltd., 2009. - P. 82.

26. Соболев В.В. Физика сверхглубокого проникновения микрочастиц в металлы / В.В. Соболев, С.М. Ушеренко // Труды Межд. Конф. Ударные волны в конденсированных средах, Киев, Украина, 16-21 сентября 2012. - Київ: Інтерпрес ЛТД, 2012. - С. 171-179.

27. Sobolev, V.V. Formation of chemical elements under superdeep penetration of lead microparticles in ferrous target / V.V. Sobolev, S.M. Usherenko // Advanced Materials ResearchVolume 47-50 
PART 1, 2008, Pages 25-28 Multi-functional Materials and Structures - International Conference on Multifunctional Materials and Structures; Hong Kong, P.R.; China; 28 July 2008 - 31 July 2008; Cod 74080.

28. Златин И.А. Физические представления о процессе разрушения твердых тел при импульсных нагрузках / И.А. Златин, Г.С. Пугачев // Труды. IІІ Всесоюзного симпозиума по импульсным давлениям. - М., 1979. - С. 151.

29. Русаков М.М. Соотношения между параметрами кратера и ударника из опытов по удару со скоростью до 30 км/с / М.М. Русаков, Б.К. Шайдуллин // Космические исследования. - 1979. - т. 17, вып.1. - С. 172-175.

30. Гелунова 3.М. Об возможности управления фазовыми превращениями при ударноволновой обработке металлов / 3.М. Гелунова, П.О. Пашков // Труды. ІІІ Всесоюзного симпозиума по импульсным давлениям. - М., 1979. - С. 171.

\section{PHYSICAL-MATHEMATICAL MODEL OF CO OPERATION OF HIGH-SPEED PARTICLE IS WITH STEEL OBSTACLE Baskevich O.S., Sobolev V.V, Usherenko S.M.}

\section{Abstract}

The use of methods of high-energy treatment of materials in a complex with other types of physical influences is in number priority scientific and technical researches, new technologies and materials of the different functional setting sent to creation. Application simultaneously two and the more types of physical influences on metallic surfaces are related to the receipt of new fundamental knowledge, and with the decision of such actual tasks as creation of new energy keeping technologies, receipt of new energy sources, and materials with new physical and chemical properties.

As objects researches chose co-operation of stream of microparticless with metallic obstacles and study of processes of their penetration on anomalously no-bottoms. The aim of work is a directed to the decision of fundamental tasks in area of firmness of substance and phase transformations.

It was set that in the process of penetration microparticless get to the massive metallic obstacles with speed of hitting $500.3000 \mathrm{~m} / \mathrm{s}$ on depths, that exceed $0,1 \mathrm{M}$. From these microparticless the nanomodified composition metallic material, that presents the massive metallic matrix saturated by including of new phase oriented in parallel by the closeness of about $(300 \ldots 1500) \times 10^{6} \mathrm{M}^{-2}$, is formed. Experimental data showed that "super-deep" penetration took place through deep structural transformations of material of obstacle. Structural changes will examine as a phase transition. As a result there are by volume changes in a channel zone on a draught $10^{-7} \sim 10^{-6} \mathrm{~s}$. In force of it the possible development of model suppositions, based on consideration of complex of structural changes as a "phase" transition. At certain terms in a metallic obstacle, there is the saltatory falling of resistance of material that testifies to the considerable structural changes.

The conducted mathematical modelling allowed with sufficient exactness to describe the process of super-deep penetration of microparticless in metallic targets and set the critical parameters of super-deep penetration.

It is set as a result, of mathematical modelling, that the offered model of "super-deep" penetration operates in narrow maximum terms, conditioned, mainly, by the size and speed parameters of process of collision. The worked out model allows to forecast the processes of management structural changes and accordingly physical-mechanics properties of the processed materials and is acceptable to development of technological processes of alloying and strengthening

\section{References}

[1] Sobolev V.V., Baskevych O.S., Shyman L.M. \& Usherenko S.M. (2016). Mechanism of thick metal walls penetration by high-speed microparticles. Naukovyi visnyk NGU - Scientific bulletin of National Mining University, 6, 75-83. 
[2] Sobolev V.V., Taran Y.N. \& Gubenko S.I. (1997). Shock wave use for diamond synthesis. Journal de Physique IV. Colloque, 73-75.

[3] Glasmacher U.A., Lang M., Keppler H., Langenhorst F., Neumann R., Schardt D. et al. (2006). Phase Transitions in Solids Stimulated by Simultaneous Exposure to High Pressure and Relativistic Heavy Ions. Physical Review Letters, 96, 195701.

[4] Sobolev V.V. \& Usherenko S.M. (2004). Shock-wave initiation of nuclear transmutation of chemical elements. Journal de Physique. IV, 134, 977-982.

[5] Usherenko S.M. (2008). Sverchglubokoie pronikayiie microchastits v pregrady i sozdaniie kompozitsionnych materialov [Superdeep penetration of microparticless to the barriers and creation of composition materials]. Minsk:NII impulsnych processov s opytnym proizvodstvom [in Russian].

[6] Bazilevskii A.T. \& Ivanov B.A. (1977). Obzor dostizhenii mechaniki krateroobrazovaniia [Review of achievments of mechanics of craterformation]. Mekhanika obrazovaniia voronok pri udare $i$ vzryve - Mechanics of funneling at a blow and explosion. V.A. Nikolaievskii [Eds.]. (pp.178-227). Moskva: Mir [in Russian].

[7] Gennon R.E., Lashlo T.S., Lei K.E. \& Uolnik C.P. (1963). Vliianiie bombardirovki microchastitsami na opticheskiie svoistva metallov [Influence of bombardment microparticless on optical properties of metal]. Raketnaia tekhnika i kosmonavtika - Rocket engineering and cosmonautics, 3, 1, 148-157 [n Russian].

[8] Kotov N.V., Muchin V.Ja. \& Shashkova V.K. (1973). Legirovaniie aliuminiia pri skorostnom soudarenii [Alloying of aliuminum at the speed hitting]. Mettalovedeniie i prochnost materialov. Trudy Volgogradskogo politekhnicheskogo instituta - Proceedings of Volgograd polytechnical institute. Volgograd, 3, 244-252 [in Russian].

[9] Pond R. \& Glase K. (1973). Metallurgicheskiie issledovaniia i raspredelieniie energii [Metallurgical researches and distribution of energy]. Vysokoskorostnyie udarnyie javleniia - High-speed shock phenomena. V.A. Nikolaievskii (Eds.). Moskva: Mir [in Russian].

[10] Kozlov E.V., Lichagin D.V. \& Popova N.A. (1988). Dlinnomernyie oblasti napriazhenii i ikh rol $\mathrm{v}$ deformatsii strukturno-neodnorodnych materialov [Long-length areas of tensions and their role in deformation structurally of heterogeneous materials]. Sbornik trudov Fizika prochnosti i plastichnosti geterogennykh materialov -Proceedings of the Physics of durability and plasticity of heterogenous materials. (pp.3-13). Leningrad: Izdatelstvo Fisiko-tekhnicheskogo instituta [in Russian].

[11] Chernyi G.G. (1987). Mechanism anomalnogo soprotivleniia pri dvizhenii tel v tverdykh sredakh [Mechanism of anomalous resistance at motion in hard environments]. DAN SSSR. Teoriia uprugosti - RAS USSR. Theory of elasticity, 292, 6, 1324-1328 [in Russian].

[12] Grigorian S.S. (1987). O prirodie "sverkhglubokogo" pronikaniia tverdykh mikrochastits v tverdyie materialy [About nature of the "super-deep penetrating" of hard microparticless in hard materials]. DAN SSSR. Mekhanika - RAS. Mechanics, 292, 6, 1319-1322 [in Russian].

[13] Rumiantzev B.V., Bazanov O.V. \& Misanochnikov A.A. (1991). Issledovaniie dinamicheskikh kharakteristik potoka legiruiushchikh chastitz kumuliativnogo zariada VV. Razrabotka vzryvnykh ustroistv dlia sozdaniia potokov razlichnoi formy i geometrii [Research of dynamic descriptions of stream of alloying particles of cumulative charge of explosives]. Development of explosive for creation of stream of different form and geometry]. Preprint SKTB "Tekhnolog" - Preprint SKTB "Technologist". Leningrad, 69. [in Russian].

[14] Rakhimov A.E. (1994). Kachestvennaia model sverkhglubokogo pronikaniia [Quality model super-deep penetrating]. Vesti Moskovskogo universiteta. Matematika. Mekhanika - Bulletin of Moscow University. Mathematics. Mechanics, 1, 5, 72-74. [in Russian].

[15] R.F. Trunina (Eds.). (1992). Svoistva kondensirovannykh veshchestv pri vysokikh davleniiakh $i$ temperaturakh [Properties of the condensed substances at high pressures and temperatures]. Arzamas: VNIIEF [in Russian]. 
[16] Kanel G.I., Razerienov S.V., Utkin A.V. \& Fortov V.E. (1996). Udarno-volnovyie javleniia v kondensirovannykh sredakh [Shock-wave phenomena in the condensed environment]. Moskva: "Janus" [in Russian].

[17] Sobolev V.V. (2003). Fizika impulsnoi obrabotki materialov [Physics of impulsive treatment of materials]. ART PRESS. V.V. Sobolev [Eds.]. Dnepropetrovsk [in Russian].

[18] Danilenko V.V. (2010). Vzryv: fizika, tekhika, tekhnologiia [Explosion: physics, technics, technology]. Moskva: Energoatomizdat [in Russian].

[19] Deribas A.A. (1980). Fizika uprochneniia i svarki vzryvom [Physics of work-hardening and welding by an explosion]. Novosibirsk: Nauka [in Russian].

[20] Andilevko S.K., Gorodtzov V.G., Kozorezov K.I. \& Usherenko S.M. (1984). Issledovaniie effektov vzaimodeistviia mikrochastits $\mathrm{s}$ metallicheskoi misheniu $\mathrm{v}$ usloviiakh vysokikh davlenii [Research of effect of co-operation of microparticless with a metallic target in the conditions of high pressures]. Sb. Fizika i tekhnika vysokikh davlenii - Physics and technique of high pressures. Kiev: Naukova dumka, 17, 82-85 [in Russian].

[21] Kreimer G.S. (1971). Prochnost tverdykh splavov [Durability of carboloy]. Moskva: Nedra [in Russian].

[22] Lavrentiev M.A. \& Shabat B.V. (1977). Problemy gidrodinamiki i ikh matematicheskiie modeli [Problems of hydrodynamics and their mathematics models]. Moskva: Nauka [in Russian].

[23] Sobolev V.V. \& Usherenko S.M. (2004). Obrazovaniie plazmy - kak veroiatnaia prichina lokalnykh razrushenii v structure materialov pri udarno-volnovoi obrabotke [Formation of plasma as credible reason of local destructions in the structure of materials at shock-wave treatment]. Ukrainskii soiuz inzhenerov-vzryvnikov. Informatsionnyi buleten - Ukrainian union of engineers and shotfirers. Informative bulletin, (pp. 19-26), 1(8) [in Russian].

[24] Sobolev V.V. \& Usherenko S.M. (2005). Obrazovaniie plazmy v udarno-volnovykh protsesakh [Formation of plasma is in shock-wave processes]. Fizika i tekhnika vysokikh davlenii - Physics and technique of high pressures, 15, 2, 86-95 [in Russian].

[25] Sobolev V.V. \& Usherenko S.M. (2009). Formation of Plasma Focus at Superdeep Penetration of Microparticles in Solid. Nonequilibrium Phenomena: Plasma, Combustion Atmosphere. G.D.Roy, S.M. Frolov, A.M.Starik [Eds.]. (p. 82). Moscow: Torus Press Ltd.

[26] Sobolev, V.V. \& Usherenko S.M. (2012). Fizika sverkhglubokogo proniknoveniia mikrochastits $\mathrm{v}$ metally [Physics super-deep penetration of microparticless in metals]. Trudy Mezhdunarodnoi Konferentsii Udarnyie volny $v$ kondensirovannykh sredakh - Proceedings of the International Symposium "Shock waves are in the condenced enviroments. (pp. 171-179). Kyiv: Interpres LTD, [in Russian].

[27] Sobolev, V.V. \& Usherenko S.M. (2008). Formation of chemical elements under superdeep penetration of lead microparticles in ferrous target. International Conference on Multifunctional Materials and Structures. (pp. 25-28). Hong Kong, P.R.; China; 28 July 2008 - 31 July 2008; Cod 74080 .

[28] Zlatin I.A. \& Pugachev G.S. (1979). Fizicheskiie predstavleniia o protsesse razrusheniia tverdykh tel pri inpulsnykh nagruzkakh [Physical views about the process of destruction of solids at the impulsive loading. Trudy III Vsesoiuznogo symposiuma po impulsnym davleniiam - Proceedihgs of the III All-Union Symposium on impulsive pressure. (p. 151). Moskva [in Russian].

[29] Rusakov M.M. \& Shaidullin B.K. (1979). Sootnosheniia mezhdu parametrami kratera i udarnika iz opytov po udaru so skorostiu do $30 \mathrm{~km} / \mathrm{s}$ [Relations by the parameters of crater and shockworker from experiments on a blow with speed at to $30 \mathrm{~km} / \mathrm{s}]$. Kosmicheskiie issledovaniia Space researches, 17, 1, 172-175 [in Russian].

[30] Gelunova Z.M. \& Pashkov P.O. (1979). Ob vozmozhnosti upravleniia fazovymi prevrashcheniiami pri udarnovolnovoi obrabotke metallov [About possibility of management by phase transformation at shock-wave treatment of metals]. Trudy. III Vsesoiuznogo symposiuma po impulsnym davleniiam - Proceedihgs of the III All-Union Symposium on impulsive pressure. (p. 171). Moskva [in Russian]. 